\title{
Tactics and practices of the alcohol industry in Latin America: What can policy makers do?
}

\author{
Ce Zhang and Maristella Monteiro \\ Pan American Health Organization, Washington, DC, United States
}

\begin{abstract}
Aim: This paper describes the practices and tactics of the alcohol industry in Latin America, focusing on industry globalization and consolidation, implementation of research studies, marketing, and corporate responsibility initiatives, and discusses how these areas of influence may have an impact on alcohol policy development in this region.

Design: The information provided here is drawn from an international literature review, news websites, and informal communications with officials in Ministries of Health and researchers from Latin America, and from annual reports and websites sponsored or maintained by major alcohol companies operating in Latin America.
\end{abstract}

Setting: Latin America and Caribbean Region

Findings: Industry globalization and consolidation, implementation of research studies, marketing, and corporate responsibility initiatives are major activities of the alcohol industry in Latin America that can influence alcohol policy making.

Conclusions: We conclude that implementing effective alcohol control policies is likely to fail if the influence and actions of the alcohol industry cannot be managed by policy makers in countries of this region. There is a need to increase knowledge of the alcohol industry's role and actions and of its conflicts of interest with public health, and to build capacity across various sectors of government to implement effective policies, using clear rules for engagement. Research on alcohol marketing, corporate social responsibility practices and the industry's influence on policy making should be a priority in emerging markets in general, but particularly in Latin America and the Caribbean.

Alcohol consumption is the leading risk factor for mortality and morbidity in most countries in the Americas region (Lim et al., 2012; Monteiro, 2007; Rehm \& Monteiro, 2005). With the adoption of the Global Strategy to Reduce Harmful Use of Alcohol by the World Health Assembly (WHA) in 2010 and a regional plan of action by the Directing Council of the Pan American Health Organization (PAHO) in 2011, these countries are attempting to develop and implement alcohol control policies. However, barriers to such developments may be presented by alcohol producers, distributors and sellers, which are influential and have no desire to see a decrease in alcohol consumption, preferring a weakly regulated alcohol market in which they can maximize their profits. In the Latin American and Caribbean (LAC) region, drinking age restrictions are poorly enforced, and most countries have outdated taxation policies and very limited controls on the availability and marketing of alcoholic beverages (Transportation Research Board, 2007).
Latin America is considered an emerging market for the alcohol industry because of its economic development (GDP is projected to grow at 3.8\% to $4 \%$ in 2013, from 3\% in 2012 (World Bank, 2012)), high proportion of potential young consumers (adolescents and youth account for 18 percent of the population (United Nations Population Fund, 2011)), and significant proportion of people aged 15 years or older who were abstainers (49.2\%, ranging from $17.5 \%$ in Argentina to $73.8 \%$ in Nicaragua (World Health Organization, 2011)). Despite the strong alcohol market potential in Latin America, little information is available on the scope and reach of industry activities which might be influencing policy making in these countries.

The objective of this paper is to describe practices and tactics of the alcohol industry in Latin America and to assess how they may have an impact on alcohol policy development. 


\section{Method}

The information provided here is drawn from an international literature review, news websites, and informal communications with officials in Ministries of Health and researchers from Latin America, and from annual reports and websites sponsored or maintained by major alcohol companies operating in Latin America, such as SABMiller, AB-InBev, Diageo, and Heineken. These alcohol companies have a large influence in Latin America, owning a majority share of the alcohol market in the region and supporting Corporate Social Responsibility initiatives (CSRs) and Social Aspects Organizations (SAOs) based in Latin American countries. Our report emphasizes large countries in Latin America, such as Brazil and Mexico, because their large populations make them profitable markets for the alcohol industry. Following the international literature on global corporations (Babor et al., 2010; Steinus, \& Babor, 2010), we focused on four major aspects of the alcohol industry in Latin America: industry globalization and consolidation, implementation of research studies, marketing, and corporate responsibility initiatives.

\section{Results}

\section{Alcohol Industry Globalization and Consolidation}

Alcohol industry globalization and consolidation has led to the dominance of a handful of large corporations. Global brewers control the majority of the market in 12 Latin American countries, accounting for more than $90 \%$ of beer sales in eight of those countries (Babor et al., 2010). One example of a successful entry by a global alcohol company into a new Latin American market is Diageo's expansion in Brazil, where in 2005 the company's leadership noted that they had achieved a spirits volume increase of $21 \%$, compared with 3\% globally (Walsh, 2005).

The largest global alcohol corporations are taking control of local companies in Latin America. For example, between 2002 and 2010, Heineken bought the Baru brewery group in Panama, a 50\% share of Chilean brewer
Compañía Cervecerias Unidas S.A., and the beer operations of FEMSA, one of the largest Mexican brewers (de la Merced, 2010). Currently, Heineken and another major alcohol corporation, Anheuser Busch-InBev (AB-Inbev), are also competing to buy the Dominican Republic's biggest brewer, Cerveceria Nacional Dominicana (CND), which is the brewer of Presidente, a popular beer in several Caribbean islands and in the United States.

Alcohol companies have entered into new markets in Latin America by buying new plants, functioning as distribution partners (e.g., Diageo has partnered with Tequila Cuervo La Rojeña, the Mexico-based maker of Jose Cuervo), creating joint ventures, buying shares in existing companies, and acquiring and marketing cheap and successful local products alongside more expensive international brands. A more aggressive tactic is to simply buy the local competitor, as AB-InBev did by purchasing full ownership of Quinsa, a Luxembourg-based holding company for breweries in Argentina, Bolivia, Chile, and Paraguay (Babor et al., 2010). Another example is the 2002 purchase of Kaiser, Brazil's second-largest brewery, by Canadian brewer Molson, which then sold a 20\% stake to Heineken (Heineken N.V., 2012). International alcohol brands have made their way to markets in Latin America through mergers and joint ventures with local brewing companies such as Quilmes in Argentina, AMBEV in Brazil, and Bavaria in Colombia (Economic Commission for Latin America and the Caribbean [ECLAC], 2005).

Once established in emerging markets in Latin America, the alcohol industry can extend production, incorporate local brands into global brands, and promote marketing, distribution and sales. Table 1 lists local alcohol brands made in Latin America that were bought by leading global alcohol companies and incorporated into their global brands (Anheuser-Busch, 2011; Diageo, 2011; Heineken N.V., n.d.). SABMiller, despite owning several Latin American beer brands, has not incorporated any local brands into their global strategy (SABMiller, 2012). Overall, globalization and consolidation have contributed to the expansion of the alcohol industry in the Latin American region.

Table 1

National brands in Latin America part of global brands

\begin{tabular}{lll}
\hline National brand/local alcohol company/country & Type (beer/wine/spirits) & Global alcohol company (date of acquisition) \\
\hline Jose Cuervo/Tequila Cuervo La Rojeña/Mexico & Spirits & Diageo (owns international distribution rights) \\
Red Stripe Lager/Desnoes \& Geddes/Jamaica & Beer & Diageo (1993) \\
Captain Morgan/Seagram Company/Jamaica & Spirits & Diageo (2001) \\
Sol/Fomento Economico Mexicano/Mexico & Beer & Heineken (2010) \\
Dos Equis/Fomento Economico Mexicano/Mexico & Beer & Heineken (2010) \\
Tecate/Fomento Economico Mexicano/Mexico & Beer & Heineken (2010) \\
Corona Extra/Cervecería Modelo/Mexico & Beer & Anheuser-Busch Inbev (2012) \\
\hline
\end{tabular}




\section{Marketing}

The global alcohol industry is driven by marketing. In 2006, Diageo spent $15.5 \%$ of its net sales on marketing (Hill, 2008). Alcohol producers are the main advertisers of alcoholic beverages, promoting alcohol brands through advertisements, sponsorships, direct marketing and media, such as the internet, television, radio, and print. Forms of direct marketing include promotions such as discount pricing, branded merchandise, and promotional toys with an alcohol theme. Successful marketing has a great impact on alcohol sales, as was shown in 2006 and 2007, when Diageo reported growth in sales of whiskey and ready-todrink products (including a $40 \%$ increase in its Johnny Walker brand) in Brazil, Paraguay and Uruguay, driven by new distribution and advertising campaigns, sponsorship, and direct promotions (Hill, 2008).

Industry sponsorship of sports, music, and cultural events is another common marketing strategy, one that brings the promotion of alcohol products directly into people's lives (Buchanan, \& Lev, 1989; Klein, 2000). Alcohol companies spend millions of dollars to sponsor major international sports events, such as the FIFA Soccer World Cup. In 2003, legislation passed by the Brazilian government prohibited the sale of alcohol in football stadiums-a public-health-protecting policy aimed at minimizing fan violence at soccer matches (Caetano, Pinsky, \& Laranjeira, 2012). Since Brazil is hosting the 2014 FIFA World Cup, which is sponsored by Budweiser from Anheuser-Busch, in June 2012 the Brazilian government decided to sign into law a bill that will temporarily suspend the restriction on the sale of alcoholic beverages during 2014 World Cup matches (Caetano et al., 2012; CNN, 2012), despite public outcry.

The increasing alcohol consumption in the region is a matter of concern (Inter-American Drug Abuse Control Commission [CICAD], 2011), and the industry is often opportunistic in targeting vulnerable groups, especially young people, for marketing campaigns (Casswell, 2004). A brand may be marketed to young people in a range of roles: showcasing attractive new technology, providing sponsorships of events, and presenting appealingly designed new beverages and packaging (Mosher \& Johnsson, 2005; Steinus \& Babor, 2010). In Brazil, extensive alcohol advertising on television reaches millions of children, and has contributed to the $10 \%$ increase in alcohol consumption each year (Laranjeira, 2007). Absolut Vodka, a brand owned by Pernod Ricard, produced two cinema commercials about its brand, titled "BeatCrazy" and "Hey Stranger," that were screened in cinemas throughout Mexico and Venezuela (Musonera \& Hemley, 2008) to audiences of all ages. A recent initiative from AMBEV, in association with other private industries in Brazil, is to encourage customers to support major soccer teams by purchasing a team loyalty card, which can be used to obtain discounts on products and services, including a 5$10 \%$ discount on beer at various supermarkets.

Social media, such as YouTube, Facebook, and Twitter, are commonly used to target younger people (Centre on Alcohol Marketing and Youth [CAMY], 2011).
ComScore, a global social media analysis service, reported that of the top 10 countries in the world for social media usage in hours per person per month, 5 are in Latin America (Argentina, Chile, Colombia, Peru, and Venezuela) (Delgado, 2012), with Facebook being the most popular social media network (Synthesio, 2011). An example of the alcohol industry's use of social media can be found in Argentina, where Quilmes used the technology to publicize promotional events in night clubs. At these events, women are offered free beer until they have to use the bathroom (Infobae, 2013). The use of these technologies for alcohol marketing could prove to be particularly effective in Latin American countries, allowing global alcohol companies to reach a vast audience and seek growth and profitability in developing economies.

As a way of avoiding legislative measures, the alcohol industry developed voluntary self-regulatory codes on marketing practices, which have no clear sanctions associated with their violation. A recent analytic essay by Babor and Robaina (2013) noted that public health research has begun to question the effectiveness of, and level of adherence to, these voluntary self-regulation practice codes. Research studies have found significant violations of such self-regulatory codes in many countries globally, including Brazil (Vendrame, Pinsky, Souze, \& Babor, 2010).

\section{Implementation of Research Studies}

In response to the expressed need for research evidence to inform policy, the alcohol industry has sponsored research studies in many parts of the world, including Latin America. Cerveceros Latinoamericanos, a conglomerate of the beer producers of Latin America, funded a large epidemiological study related to alcohol consumption patterns in nine Latin American countries, coordinated by researchers from Costa Rica's Facultad Latinoamericana de Ciencias Sociales (FLASCO) (Sojo, 2012). An inherent conflict of interest is created by the studies' sponsorship by local brewers in each of the nine countries; furthermore, none of the studies was reviewed by an ethics committee, as is required by law in several of the participating countries when research on human subjects is planned. In addition, their use of a nonstandard criterion for defining severity of alcohol problems using the AUDIT is misleading because they did not use all the AUDIT items and neglected to report the proportions identified as drinking at hazardous and harmful levels (Babor, HigginsBiddle, Saunders, \& Monteiro, 2001). When FLACSO organized an event to disseminate the results, their invitation letter to Ministries of Health from Latin America stated that the event was "on the occasion of the World Health Assembly (WHA)” in May 2012 in Geneva, despite its being unrelated to any activity of the WHA. A similar event was planned "on the occasion of the Pan American Sanitary Conference" (September 2012) in Washington, D.C., but was cancelled following a request from the PAHO Director to be dissociated, directly or indirectly, from the event, and a policy brief to all delegations from the region.

The alcohol industry has attempted to involve international public health agencies in their "assessments." For example, 
beer, wine, and spirits producers have partnered with global research firms such as GlobeScan and Euromonitor International, and requested interviews with PAHO representatives in order to contribute their views and plans.

The industry also sponsors social aspect organizations, operating globally or in emerging markets, which can implement research studies and allow the industry to broaden its policy influence and respectability. One such organization is the International Center for Alcohol Policies (ICAP) (Jernigan, 2012), an industry-sponsored Americanbased think tank that aims to promote government and industry collaboration on issues connected to alcohol consumption and abuse. ICAP's influence stems from its high output of scientific conferences, books, reports and briefing papers, which generally argue for alcohol control policies that focus on individual patterns of drinking, such as the behavior of heavy drinkers (Caetano, 2008), rather than the population-based measures, such as taxation and restricting access to alcohol (Farrell, 2007), that are advocated by public health researchers and the WHO. In 2007, ICAP held a meeting in Chile entitled: A Workshop on Self-Regulation in the Latin America Region (International Center for Alcohol Policies (ICAP) and Consejo de Autorregulación y Ética Publicitaria (CONARChile, 2007), in which the meeting's goal was to promote self-regulation in Latin America as a complement to government regulation. However, since Chile does not have any legally binding alcohol marketing regulations (WHO, 2011), the meeting's purpose implies instead a complement to no government regulation. In addition, the policy options and interventions recommended in the WHO Global Strategy to Reduce the Harmful use of Alcohol include "setting up regulatory and co-regulatory frameworks, preferably with a legislative basis, and supported when appropriate (emphasis added) by selfregulatory measures for alcohol marketing” (WHO, 2010). Self-regulatory measures per se are not among the policy options.
ICAP has been in direct contact with state authorities in Mexico to take responsibilities over education and training of law enforcement related to drink driving, areas which are beyond the role of the alcohol industry as producers, distributors, sellers or marketers of alcoholic beverages (Chan, 2013). For example, ICAP had been promoting a campaign focusing on drink driving awareness training of collegiate-level youth and training of law-enforcement agencies in Puebla, Mexico.

More recently, ICAP and 13 of the world's leading beer, wine, and spirits producers have announced a five-year joint commitment, beginning in 2013, of 10 targeted actions in five areas to reduce the harmful consumption of alcohol (ICAP, 2012a). Although the industry will hire third-party organizations to audit and publicly report on their compliance with these new commitments, the industry's goals are likely to remain at odds with public health. As an example, the midterm report commissioned by ICAP on the evaluation of global actions on harmful drinking suggests that the impact of ICAP's initiatives would be higher if they targeted areas where PAHO/WHO is less active (Channel Research, 2011).

\section{Corporate Social Responsibility}

Corporate Social Responsibility (CSR) is used by the alcohol industry to present a responsible face to the public, while providing another method to promote the interests of alcohol companies and allow them to access markets and influence national-level policy decisions. Examples of major alcohol companies and organizations that have CSR policies and that possess strong influence in Latin America are Anheuser-Busch InBev (AB-InBev), SABMiller, Diageo, and Heineken. Descriptions of these companies' main activities in Latin America are listed in Table 2. Data from Table 2 comes from the Worldwide Brewing Alliance Social Responsibility website (WBA) as well as the annual social responsibility reports of the alcohol companies.

Table 2

Activities of specific alcohol corporations in Latin America

\begin{tabular}{|c|c|c|c|c|c|}
\hline Corporation & Social responsibility campaigns & $\begin{array}{l}\text { Code of } \\
\text { communications }\end{array}$ & $\begin{array}{c}\text { Hosted } \\
\text { conference/ } \\
\text { seminars }\end{array}$ & Research & $\begin{array}{l}\text { Social aspect } \\
\text { organizations }\end{array}$ \\
\hline $\begin{array}{l}\text { Anheuser-Busch } \\
\text { Inbev (AB-Inbev) }\end{array}$ & $\begin{array}{l}\text { Brazil, Uruguay, Argentina, Bolivia, } \\
\text { Paraguay }\end{array}$ & $\begin{array}{l}\text { Global code of } \\
\text { communications }\end{array}$ & Brazil & $\begin{array}{l}\text { Argentina, } \\
\text { Brazil }\end{array}$ & CISA \\
\hline SABMiller & $\begin{array}{l}\text { Colombia, Ecuador, El Salvador, Honduras, } \\
\text { Panama, Peru }\end{array}$ & $\begin{array}{l}\text { Global code of } \\
\text { communications }\end{array}$ & El Salvador & None & None \\
\hline Diageo & $\begin{array}{l}\text { Argentina, Chile, Brazil, Puerto Rico, } \\
\text { Mexico, Colombia, Costa Rica, Dominican } \\
\text { Republic, Ecuador, Paraguay, Peru, } \\
\text { Uruguay, Venezuela, Jamaica, Haiti, El } \\
\text { Salvador }\end{array}$ & $\begin{array}{l}\text { Global code of } \\
\text { communications }\end{array}$ & None & None & FISAC \\
\hline Heineken & Brazil, Mexico & $\begin{array}{l}\text { Global code of } \\
\text { communications }\end{array}$ & Mexico & None & None \\
\hline
\end{tabular}


A key CSR promoting strategy employed by the alcohol industry is to fund a network of local, regional, and national Social Aspects Organizations (SAOs) which sponsor prevention initiatives and industry-friendly views on alcohol problems and policies (Anderson, 2002, 2004). Most SAOs funded by the alcohol industry are based in non-Latin American countries; however, there are notable SAOs in Latin America, including Fundación de Investigaciones Sociales A.C. (FISAC) in Mexico, of which Diageo is a member, and the Center for Information on Health and Alcohol (CISA) in Sao Paulo, Brazil. FISAC conducts educational programs on responsible alcohol consumption, and also sponsors a research center that focuses on collecting and analyzing information on national and international alcohol practices. Funded by AMBEV, CISA's main activity is to use national and international research findings to disseminate information on alcohol and health. CISA also promotes educational programs funded by the alcohol industry. For example, in 2004, CISA produced a booklet, "How to Talk About Alcohol with Your Children." It was handed out to all 19 of the NGOs belonging to the "Jovens de Responsa" social responsibility initiative of AMBEV in Brazil. The messages are ambivalent, and simply put the responsibility for excessive alcohol consumption on young people themselves and on their parents, who should have better educated them. Moreover, due to the "Jovens de Responsa” program, AMBEV funded the government of the State of São Paulo to implement an educational program in 28 public schools in 2010-2011 (Companhia de Bebidas das Américas - Ambev, 2011), aimed at preventing drinking before 18 years of age. No evaluation of its impact has been done. AMBEV is also working with bar owners in marginalized neighborhoods of São Paulo: a bar is remodeled (new furniture, lights, external and interior painting) if its owner is not selling alcohol to minors.

\section{Discussion}

Monitoring the activity of the alcohol industry in Latin American countries is of considerable importance, as these countries have a large but still very limited regulated alcohol market. Alcohol prices, availability and marketing are weakly controlled, creating the perfect environment for industry investment and promotion of alcohol consumption. The industry's globalization and consolidation, marketing, advertising and sponsorship practices, research initiatives and CSR practices combine to construct an image of a "good business" model, but one in which public health is not accounted for.

The alcohol industry is increasingly able to influence the implementation of alcohol policy at local and national levels, by promoting their own initiatives instead of population-based policies, circumventing national legislation, or lobbying against effective policies based on the available evidence. Future alcohol policy discussions should be conducted with an awareness of the industry's role, tactics and aims in each country. In order to protect public health, it is necessary to build the capacity of various government sectors and organizations of civil society to recognize and address conflicts of interest around alcohol policy, using appropriate rules of engagement and negotiation. Indeed, the Ministries of Health of 30 countries in the Americas made recommendations to PAHO on these issues in the national alcohol focal points that they presented at the first regional meeting of the Pan American Network on Alcohol and Public Health held in Mexico City, Mexico, in August 2012 (PAHO, 2012).

\section{Acknowledgments/disclaimer}

The authors would like to thank Raul Caetano, David Jernigan, and Thomas Babor for their valuable comments to the manuscript. The views presented in this article are solely those of the authors and do not represent the views or policies of the Pan American Health Organization.

\section{References}

Anderson, P. (2002). The beverage alcohol industry's social aspects organizations: A public health warning (Online Publication). Retrieved from www.api.or.at/ sp/alcoholpolicy\%20dokumente/f1542_socialaspects\%20eurocare.pdf

Anderson, P. (2004). The beverage alcohol industry's social aspects organizations: a public health warning. Addiction, 99, 1376-1377. doi:10.1111/j.1360-0443. 2004.00866.x

Anheuser-Busch. (2011). AB-InBev annual report 2011. Leuren, Belgium: Author. Retrieved from http:// www.abinbev.com/pdf/AB_InBev_AR11_EN.pdf

Babor, T., Caetano, R., Casswell, S., Edwards, G., Giesbrecht, N., Graham, K., . . . Rossow, I. (2010). Alcohol: No ordinary commodity. Research and public policy (2nd ed.). Oxford, England: Oxford University Press.

Babor, T., Robaina, K. (2013). Public health, academic medicine, and the alcohol industry's corporate social responsibility activities. American Journal of Public Health, 103, 206-214. doi:10.2105/AJPH.2012. 300847

Babor, T. F., Higgins-Biddle, J. C., Saunder, J. B., \& Monteiro, M. G. (2001). AUDIT The Alcohol Use Disorders Identification Test. Guidelines for use in primary care (2nd ed.). Geneva, Switzerland: World Health Organization, Department of Mental Health and Substance Dependence.

Buchanan, D., Lev, J. (1989). Beer and fast cars: How brewers targets blue-collar youth through motor sports sponsorship, Washington, DC, United States: AAA Foundation for Traffic Safety.

Caetano, R. (2008). About smoke and mirrors: The alcohol industry and the promotion of science. Addiction, 103, 175-178. doi: 10.1111/j.1360-0443.2007.02104.x

Caetano, R., Pinsky, I., \& Laranjeira, R. (2012). Should soccer and alcohol mix? Alcohol sales during the 2014 world soccer cup games in Brazil. Addiction, 107, 1722-1723. doi: 10.1111/j.1360-0443.2012. 03945.x 
Casswell, S. (2004). Alcohol brands in young people's everyday lives: New developments in marketing. Alcohol and Alcoholism, 39, 471-476. doi: 10.1093/ alcalc/agh101

Centre on Alcohol Marketing and Youth (CAMY). (2011). CAMY charts alcohol industry's digital marketing, questions adequacy of industry's self-regulation to avoid exposing youth to "alcohol experience". Press Release. Retrieved from http://www.camy.org/press/ PDFs-In\%20the\%20News/CAMY-marketwatch.pdf

Chan, M. (2013). WHO's response to article. BMJ, 346, 21. doi: 10.1136/bmj.f2647

Channel Research. (2011). Evaluation of global actions on harmful drinking: A stitch in time. Midterm report. Retrieved from http://globalactions.org/LinkClick. aspx?fileticket $=$ UH50giaJdic\%3d\&tabid $=408$

CNN. (2012, January 20). World cup beer battle brewing between Brazil and FIFA. Retrieved from http://edition.cnn.com/2012/01/19/sport/football/footb all-Brazil-alcohol-FIFA/index.html

Companhia de Bebidas das Américas - Ambev. (2011). 2011 Annual report. Retrieved from http://ir.ambev. com.br/arquivos/Ambev_RA_2011_en.pdf

de la Merced, M. (2010). Heineken in deal to buy a big Mexican brewer. (Press Release). The New York Times, p. B2. Retrieved from http://www.nytimes. com/2010/01/12/business/global/12beer.html?_r=1

Delgado, A. (2012). The latest on social media in Latin America. (Press Release). Retrieved from http://latinlink.usmediaconsulting.com/2012/01/thelatest-on-social-media-in-latin-america/

Diageo (2011). Diageo annual report. London, England: Author. Retrieved from http://www.diageo.com/enrow/investor/Pages/resource.aspx?resourceid=1060

Economic Commission for Latin America and the Caribbean (ECLAC). (2005). Foreign investment in Latin America and the Caribbean. Santiago, Chile: Author. Retrieved from http://www.eclac.org/ publicaciones/xml/2/24302/lcg2309i.pdf

Farrell, M. (2007). The alcohol industry: Taking on the public health critics [Review of the book Drinking in context: patterns, interventions, and partnerships, by G. Stimson, M. Grant, M. Choquet, \& P. Garrison (Eds.)]. BMJ, 29, 673. doi: 10.1136/bmj.39337. 431667.4E

Heineken N.V. (n.d.). Heineken international brands. Amsterdam. The Netherlands: Author. Retrieved from http://www.heinekeninternational.com/products_brand s_brands.aspx

Heineken N.V. (2002). New partners in Canada and Brazil. [Press Release]. Retrieved from http://www.heineken international.com/detail_article_press.aspx?id=136600 00000338

Hill, L. (2008). The alcohol industry. In H. K. Heggenhougen \& S. Quah (Eds). International encyclopedia of public health (pp. 124-135). San Diego, CA, United States: Academic Press.

International Center for Alcohol Policies (ICAP). (2012a). Reducing harmful use of alcohol: Beer, wine, and spirits producers' commitments. (Press Release). Washington, DC, United States: Author. Retrieved from http://event.global-actions.org/Reducing\%20 Harmful\%20Use\%20of\%20Alcohol.pdf

International Center for Alcohol Policies (ICAP). (2012b). Global actions on harmful drinking. Initiatives Reporting: Industry Actions to Reduce Harmful Drinking. Retrieved from http://initiatives.globalactions.org

International Center for Alcohol Policies (ICAP) and Consejo de Autorregulación y Ética Publicitaria (CONAR-Chile). (2007). A workshop on selfregulation Latin America region meeting report. Santiago, Chile: Author. Retrieved from http:// www.icap.org/Portals/0/download/all_pdfs/ meeting _reports/Self-Reg\%20Latin\%20America\%20

Workshop.pdf

Infobae. (2013). Formosa: Escándalo por una fiesta que incita a la ingesta excesiva de alcohol. (Formosa: Scandal over a party that encourages binge drinking). [Press Release]. Retrieved from http://www.infobae. com/notas/693180-Formosa-escandalo-por-una-fiestaque-incita-a-la-ingesta-excesiva-de-alcohol.html

Inter-American Drug Abuse Control Commission (CICAD). (2011). Report on drug use in Americas. Washington, DC, United States: Author. Retrieved from http://www.cicad.oas.org/oid/pubs/DrugUse_in_ Americas_2011_en.pdf

Jernigan, D. (2012). Global alcohol producers, science and policy: The case of the International Center for Alcohol Policies. American Journal of Public Health, 102, 80-89. doi: 10.2105/AJPH.2011.300269

Klein, N. (2000). No space, no choice, no jobs, no logo. London, United Kingdom: Harper Collins.

Laranjeira, R. (2007). Brazil's market is unregulated. BMJ, 335, 735. doi: 10.1136/bmj. 39360.432940.BE

Lim, S., Vos, T., Flaxman, A. D., Danaei, G., Shibuya, K., Adair-Rohani, H., . . . Ezzati., M. (2012). A comparative risk assessment of burden of disease and injury attributable to 67 risk factors and risk factor clusters in 21 regions, 1990-2010: A systematic analysis for the Global Burden of Disease Study 2010. Lancet, 380, 2224-2260. doi:10.1016/S0140-6736(12)61766-8

Monteiro, M. (2007). Alcohol and public health in the Americas: A case for action. Washington, DC, United States: Pan American Health Organization.

Mosher, J. F., \& Johnsson, D. (2005). Flavored alcoholic beverages: An international marketing campaign that targets youth. Journal of Public Health Policy, 26, 326-342. doi: http://dx.doi.org/10.1057/palgrave.jphp. 3200037

Musonera, E., \& Hemley, D. (2008). Analysis of global marketing strategies in distilled spirits industry: Absolut vodka. The Journal of Global Business Management, 4, 76-84. Retrieved from http://www. jgbm.org/page/9\%20Etienne\%20Musonera\%20.pdf

Pan American Health Organization (PAHO). (2012). Summary report and recommendations from the first PANNAPH meeting, Pan American Health Organization, Washington, DC, United States: Author.

Rehm, J., \& Monteiro, M. (2005). Alcohol consumption and burden of disease in the Americas- implications for alcohol policy. Pan American Journal of Public 
Health，18，241-248. doi:10.1590/S1020-49892005 000900003

SABMiller. (2012). SABMiller annual report. London, England: Author. Retrieved from http://www.sab miller.com/files/reports/ar2012/2012_annual_report.p df

Sojo, C. (2012). Alcohol drinking patterns in Latin America comparative analysis of nine countries. San Jose, Costa Rica: Facultad Latinoamericana de Clenclas Sociales (FLASCO). Retrieved from http://unpan1.un.org/intradoc/groups/public/document s/icap/unpan049539.pdf

Steinus, K., \& Babor, T. (2010). The alcohol industry and public interest science. Addiction, 105, 191-198. doi:10.1111/j.1360-0443.2009.02688.x

Synthesio. (2011). Social media in Latin America. [PowerPoint Slides]. Retrieved from http://synthesio. com/corporate/wp-content/uploads/2011/02/synthesiosocial-media-in-latin-america.pdf

Transportation Research Board. (2007). Traffic safety and alcohol regulation. (Research circular E-C123) Washington, DC, United States: Author. Retrieved from http://onlinepubs.trb.org/onlinepubs/circulars/ec 123.pdf

United Nations Population Fund. (2011). Latin America \& the Caribbean. New York, NY, United States: Author. Retrieved from http://www.unfpa.org/worldwide/ lac.html

Vendrame, A., Pinsky, I., Souza e Silva, R., \& Babor, T. (2010). Assessment of self-regulatory code violations in Brazilian television beer advertisements. Journal of Studies on Alcohol and Drugs, 71, 445-451.

Walsh, P. (2005). Diageo 2005 preliminary results. Presentation slides and speech transcript. Retrieved from http://www.diageo.com/NR/rdonlyres/4DA6C67 9-x5e-4f90-8e93-ab213ffcd958/0/PaulWalshInterview Transcript.pdf.

Worldwide Brewing Alliance (WBA). (n.d.). Worldwide brewing alliance: Global social responsibility initiatives. Retrieved from http://gsri.worldwide brew ingalliance.org/php/index.php?doc_id=40

World Bank. (2012). Despite slower growth, Latin America nears historic unemployment lows. (Press Release). Retrieved from http://www.worldbank.org/en/news/ press-release/2012/10/03/despit-slower-growth-latinamerica-nears-historic-unemployment-lows

World Health Organization. (2010). Global Strategy to Reduce the Harmful Use of Alcohol. Retrieved from http://www.who.int/substance_abuse/alcstratenglishfin al.pdf

World Health Organization (WHO). (2011). Global information system on alcohol and health (GISAH) data files. Retrieved from http://apps.who.int/ghodata/ ?theme $=$ GISAH 